\title{
Seasonal changes in the white blood cell count and blood cell sedimentation rate in the European bison Bison bonasus
}

\author{
Janusz GILL
}

Gill J. 1992. Seasonal changes in the white blood cell count and blood cell sedimentation rate in the European bison Bison bonasus. Acta theriol. 37: 279 - 290.

Two hundred and forty European bison Bison bonasus (Linnaeus, 1758) were divided into 4 groups based on age and sex, and seasonal changes in the white blood cell count and blood cell sedimentation rate were studied. Seasonal cyclicity was found in the leukocyte count of mature cows (with the maximal point at the end of October) and lymphocyte percentage in young females (with maximum in mid-August). In the neutrophil, eosinophil and basophil counts, no seasonal cyclicity was found. As regards the sedimentation rate, cyclicity was found in young females and mature cows, after 60 min of sedimentation, with the maximal points in July and January, respectively.

Department of Vertebrate Animal Physiology, Zoological Institute, University of Warsaw, Żwirki i Wigury 93, 02-089 Warsaw, Poland

Key words: Bison bonasus, white blood cells, sedimentation rate, seasonal cyclicity

\section{Introduction}

The life span of white blood cells of animals is very short (16 hours, Dukes 1955; several hours to 23 days, Gutowski 1965; 6 hours in the peripheral blood and $1-2$ days in tissues, Dąbrowski 1987). The life span depends mainly on two factors: (1) the antygenity of the environment; (2) the immunological (or defence) needs of an organism. The physiological state of an organism also plays a certain role (Deptuła and Buczek 1982).

The European bison Bison bonasus (Linnaeus, 1758) is one of the largest mammals living at present in the forest environment in which the amount of light is less than in an open area. Light regulates many physiological processes, including the immunological ones (Haus et al. 1983, Shifrine and Rosenblatt 1981). In forest environment every animal is exposed to various injuries caused by bushes, branches and uprooted trees which can result in numerous wounds and infections. Each infection must be overcome without disturbances in basal physiological mechanisms. This need for defence has been shown in previous papers (Gill 1987, $1989,1990)$. In those papers it was also shown that out of 48 group-indices studied, 
23 showed seasonal cyclicity. The acrophases of those metabolic indices occurred mostly from mid-August until mid-December.

In the present work therefore arose the question whether the European bison has the ability to react to environmental factors such as seasons of the year in producing and using different forms of the white blood cells which normally are taken into consideration as parameters of health.

The sedimentation rate of blood cells depends on many factors, the most important one being the proportion of albumins to globulins in the blood plasma. From the chronobiological point of view the sedimentation rate was studied in Thoroughbred horses (Gill and Wańska 1978) and in Arabian horses (Gill and Kompanowska-Jezierska 1986).

The aim of this paper is to find if there exists a seasonal or circannual cyclicity in the leukocyte count and in all forms of these cells as well as in the blood cell sedimentation rate in Europaean bison living in free-ranging herds.

\section{Materials and methods}

The studies were carried out on the blood taken from 240 European bison, during the period from 1977 to 1990. Selection was made each month, except May and August, and in the case of young bison, except May, June, July and August. All the animals were selected for the breeding aims and shot. All the European bison were divided into four groups: Group 1, sexually immature males, $0-3$ years old; Group 2, immature females, $0-3$ years old; Group 3, mature bulls, over 3 years of age; Group 4, mature cows, over 3 years of age.

The blood was taken from the jugular vein cut immediately after the animal was shot. That procedure between the opening a vein and taking the blood lasted $2-3 \mathrm{~min}$. The blood was taken into tubes with antycoagulant, transported to the laboratory and then the next day the analyses were made.

The haematological indices studied were determined by standard physiological methods (Kokot 1969). The number of leukocytes was determined in a Thoma-Zeiss chamber, and the percentage of various forms of leukocytes in blood smears stained by May-Grunwald-Giemsa reagent. The sedimentation rate of blood cells (PCV) after 15 and $60 \mathrm{~min}$ of sedimentation was measured in the Westergren apparatus (Pawelski 1977).

All the data were analysed statistically according to Student's $t$-test for unpared variables (Oktoba 1977). The results were analysed by the use of the least squares method, according to Halberg et al. (1967). The presence of a circannual cycle was estimated by the cosinor circle analysis (Halberg et al. 1967).

\section{Results}

\section{Leukocytes}

The mean number of leukocytes changed from $3750 \times 10^{9} /$ (Gr. 4, June), to $8190 \times 10^{9} /$ (Gr. 3, March, Table 1). In Gr. 1 and 2 this number slightly decreased from January till April and in the autumn it increased, toward the winter months 
(Fig. 1). The mean values were lower than in Gr. 3 and 4. In older bison (Gr. 3 and 4) the curves have a rather different shape, with one distinct peak in bulls, in March, and one deep drop in cows, in June (Fig. 1).

The cosinor circle analysis showed the presence of a circannual cycle in leukocyte number only in one group of European bison, i.e. in mature cows (Gr. 4). The acrophase occurred at the end of October (Fig. 2).
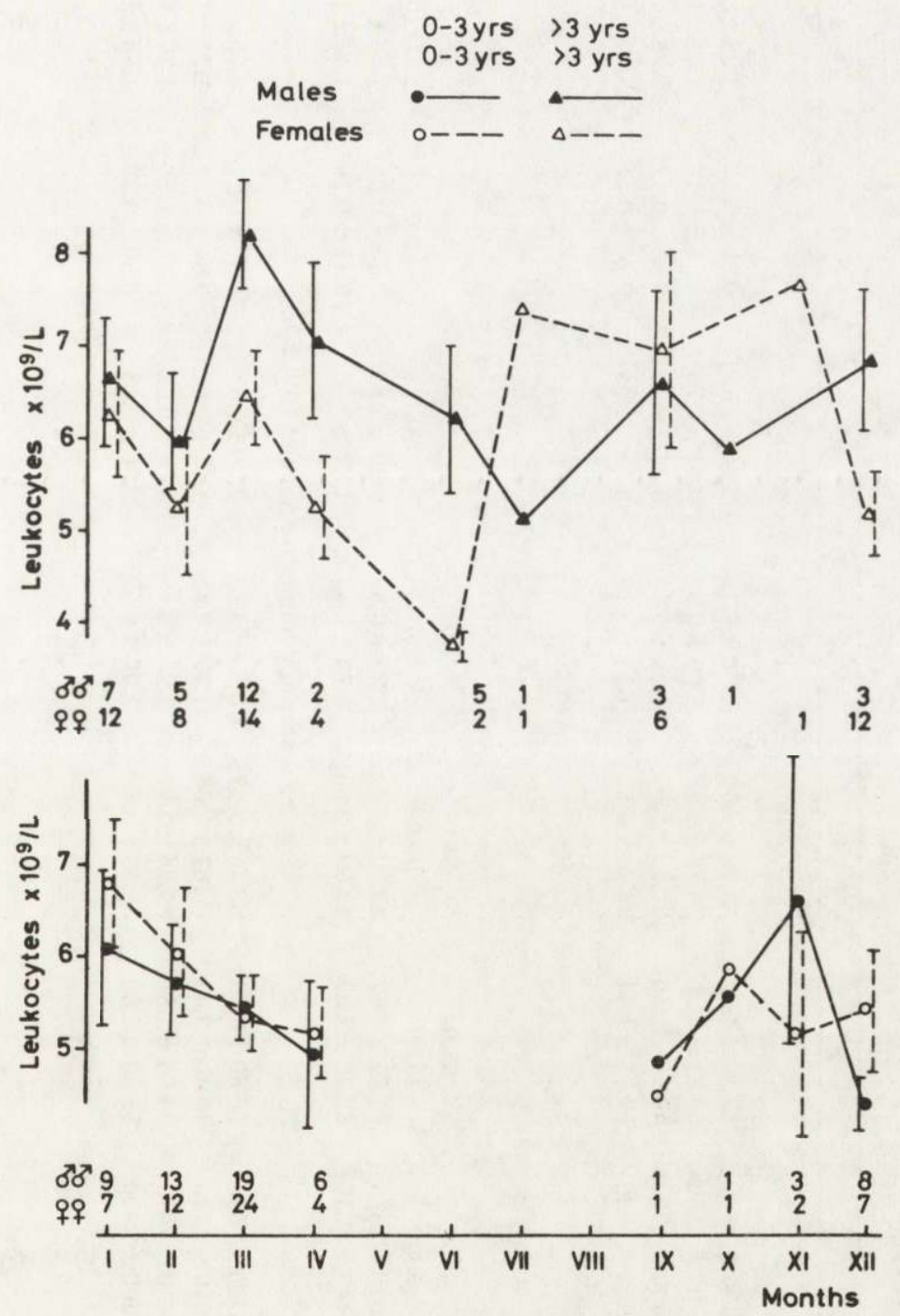

Fig. 1. Seasonal changes in the white blood cell number (leukocytes) in the blood of European bison (mears and SE). Below the curves numbers of bisons studied in each month are given. Males $(0-3$ years categorized are in Group 1; females $(0-3$ years), as Group 2; mature bulls (over 3 years), as Groul 3; mature cows (over 3 years), as Group 4. 


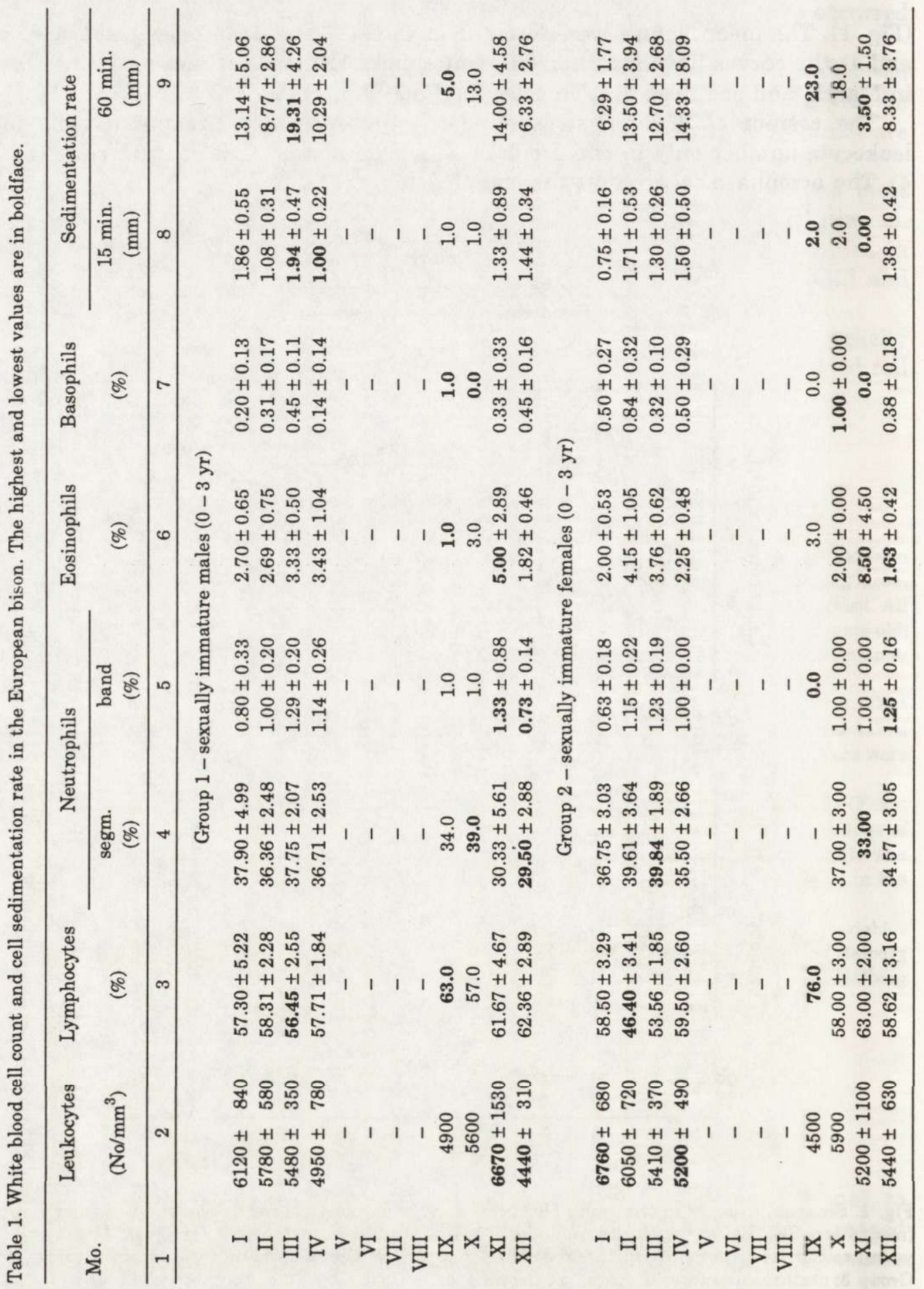




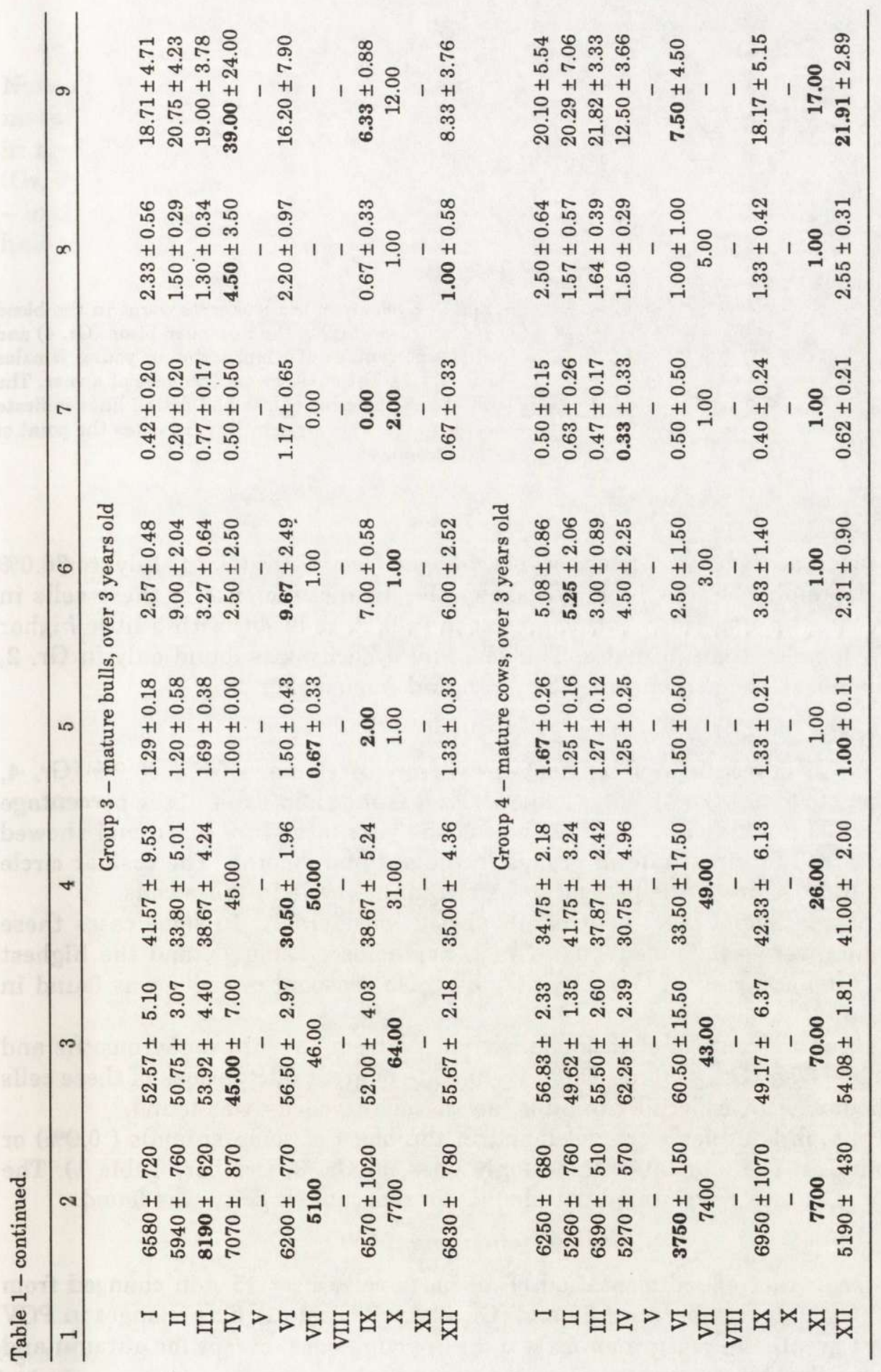




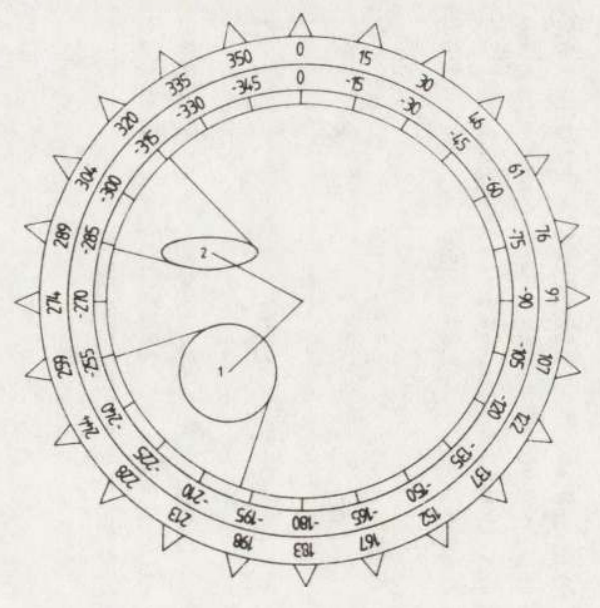

Fig. 2. Cyclicity of the leukocyte count in the blood of mature cows (2) of the European bison (Gr. 4) and of the percentage of lymphocytes in young females (1), (Gr. 2). The circle covers 365 days of a year. The ellipse means error ellipse and dotted lines indicate error range. The straight line indicates the point of the acrophase.

\section{Lymphocytes}

The mean percentage of lymphocytes changed from $43.0 \%$ (Gr. 4, July) to $76.0 \%$ (Gr. 2, September, Table 1). Fig. 3 shows the distinct increase of these cells in autumn months, aspecially this can be seen in mature bison, with a little higher levels in females than in males. The seasonal cyclicity was found only in Gr. 2, young females. The acrophase occurred in mid-August (Fig. 2).

\section{Neutrophils}

The mean percentage of segmented neutrophils changed from $26.0 \%$ (Gr. 4, November) to $50.0 \%$ (Gr. 3, July, Table 1). As it is shown in Table 1, the percentage of these cells fluctuated in the first half of the year in mature bison and showed a rather steady decrease in all groups in the autumn months. The cosinor circle analysis did not prove the presence of a circannual cycle in these cells.

The percentage of band neutrophils varied considerably. In some cases these neutrophils were not found $(0.0 \%, \mathrm{Gr} .2$, September, Table 1$)$, and the highest level of $2.0 \%$ occurred in Gr. 3 (September). No seasonal cyclicity was found in these cells.

The mean percentage of eosinophils changed from $1.0 \%$ (in many months and groups) to $9.67 \%$ (Gr. 3, June, Table 1). In spite of great fluctuations of these cells throughout a year, especially in bulls, no seasonal cyclicity was found.

The basophils either were not found in the blood of some animals $(0.0 \%)$ or were found in the amount of $2.0 \%$ (only ones, in Gr. 3, October, Table 1). The majority of values were stated within $1 \%$. No seasonal cyclicity was found.

\section{Sedimentation rate $(\mathrm{PCV})$}

The mean rate of sedimentation of all blood cells after 15 min changed from $0.0 \mathrm{~mm}$ (Gr. 2, November) to $4.50 \mathrm{~mm}$ (Gr. 3, April, Table 1). The changes in PCV rate were greater in mature animals than in young ones, except for autumn and winter months. No seasonal cyclicity was found. 
The mean values of the PCV after 60 min changed from $3.50 \mathrm{~mm}(\mathrm{Gr}$. 2, November) to $39.00 \mathrm{~mm}$ (Gr. 3, April). The highest fluctuations were found in mature bulls (Fig. 4), and this rate decreased toward the winter months, but not in mature cows. The seasonal cyclicity was found only in females. In young ones (Gr. 2, Fig. 5) the acrophase occurred in the first half of July and in mature cows - in the first days of January (Fig. 5), but the error range was very broad covering half of the year.

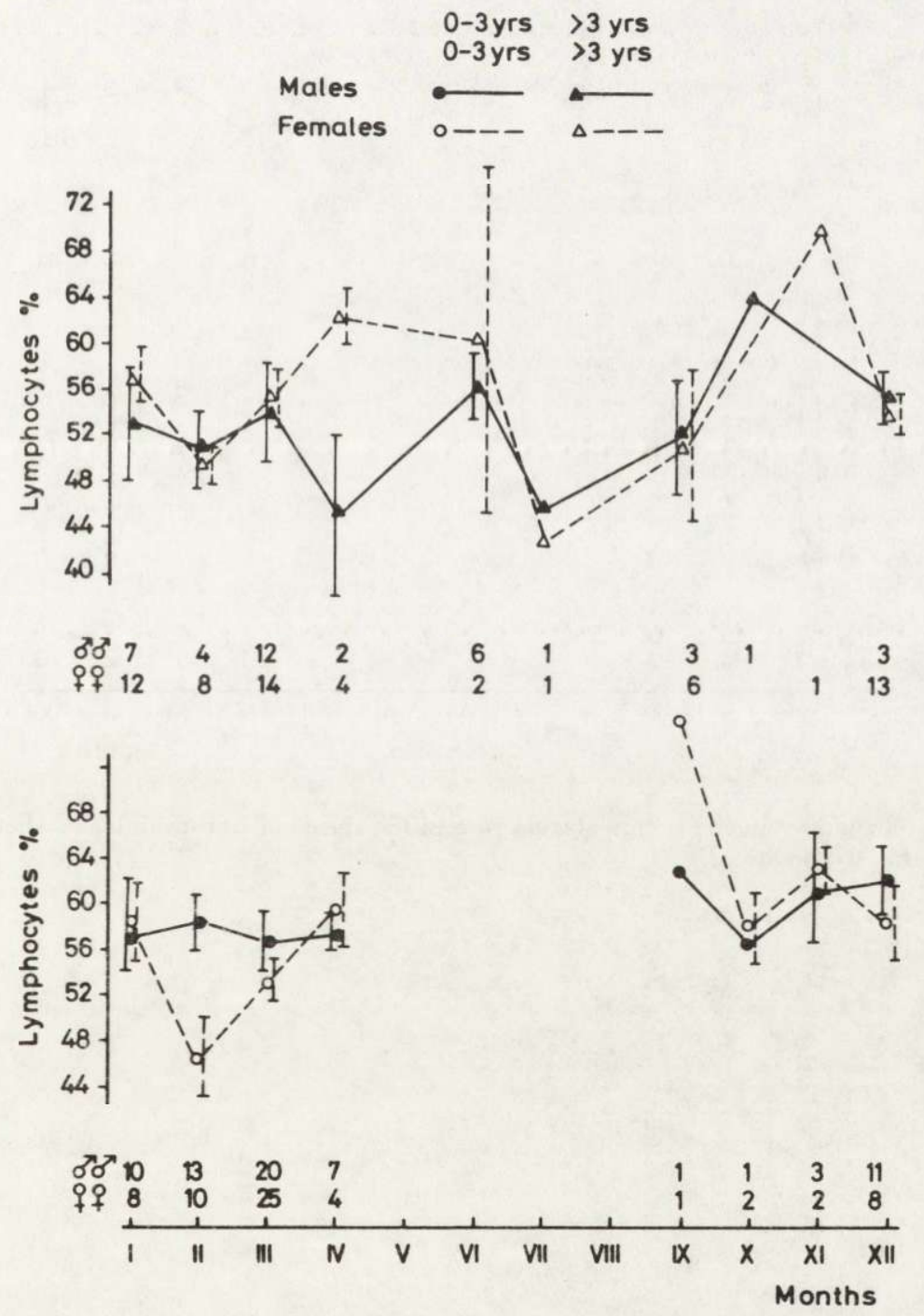

Fig. 3. Seasonal changes in the percentage of lymphocytes in the blood of European bison (see Fig. 1 for further explanation). 

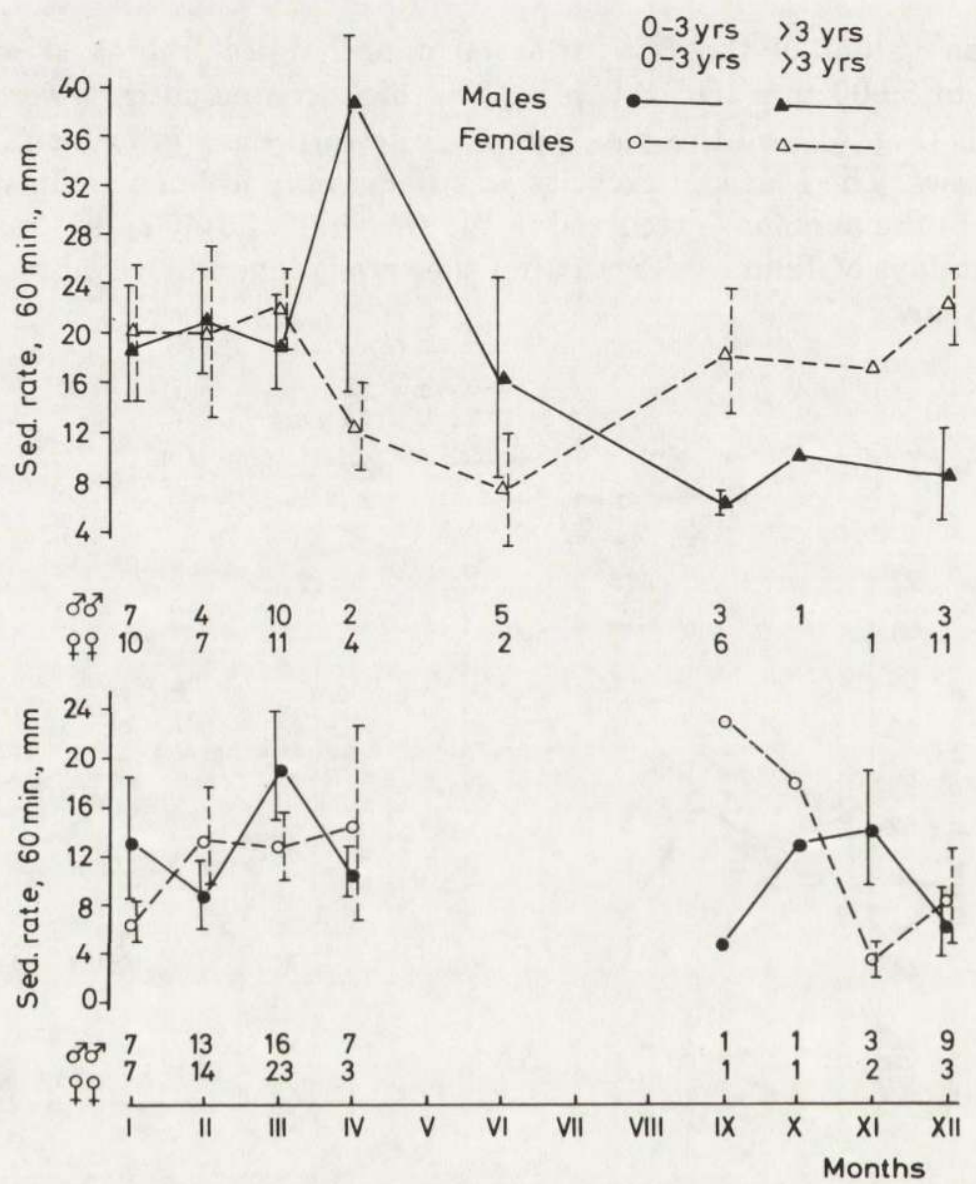

Fig. 4. Seasonal changes in the sedimentation rate in the blood of European bison after 60 min (see Fig. 1 for further explanation).

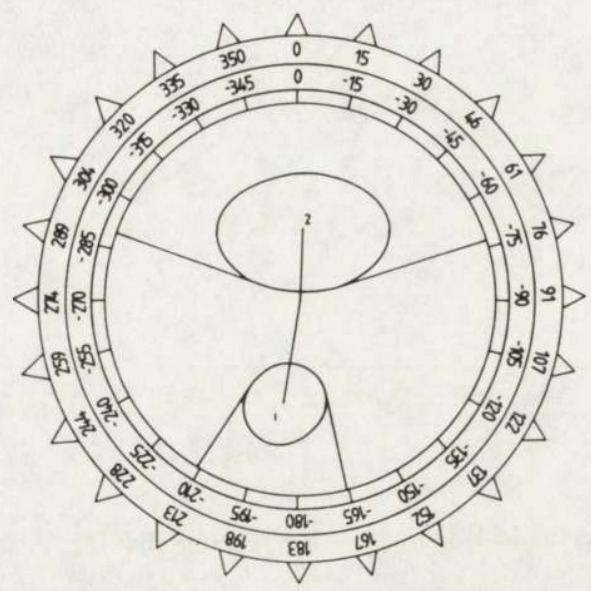

Fig. 5. Cyclicity of the sedimentation rate of cells in the blood of mature cows (2) of European bison (Gr. 4 ) and of young females (1), (Gr. 2), after $60 \mathrm{~min}$ of sedimentation (see Fig. 2 for further explanation). 


\section{Discussion}

The results obtained in this paper are not in agreement with those from previous papers, which were based on the blood taken mostly from the same bison (Gill 1989, 1990). Most of the parameters in the red blood cell system and in carbohydrate metabolism indices showed seasonal or circannual cyclicity. In this studies only two out of 24 group-indices for the white blood cell showed seasonal cyclicity. As regards the sedimentation rate of the blood cells also two out of 8 group-indices were cyclic. This means that the production and use of the white blood cells react more to other factors than to the changes of the season of the year.

All the cyclic indices were found in females. This fact agrees with earlier studies on the red blood system and carbohydrate metabolism (Gill 1989, 1990). The European bison females are more cyclic metabolically than the males are.

Despite the lack of cyclicity in studied indices, their peaks, underlined in Table 1 , are groupped rather typically: March-April -3 peaks (leukocyte number, Gr. 3; neutrophil segm. \%, Gr. 2; PCV rate, after $15 \mathrm{~min}$ and $60 \mathrm{~min}, \mathrm{Gr} .1,3$ ), June-July -2 peaks (neutrophil segm., Gr. 3, 4; PCV rate after 15 min, Gr. 4), September-November -6 peaks (leukocyte number, Gr. 1,4 ; lymphocyte $\%$, all groups; neutroph. band \%, Gr. 1; eosinophil \%, Gr. 1, 2; basophil \%, all groups; PCV rate after 15 and $60 \mathrm{~min}, \mathrm{Gr} .2$ ). So, the peaks occurred mostly in autumn months, sililarly as in previous papers. It was especially distinct in the red blood cell system (Gill 1989).

It is interesting that those forms of the white blood cells which are present in the blood in very small amounts, i.e. band neutrophils, eosinophils and basophils, did not show seasonal cyclicity, according to cosinor cycle method (Halberg et al. 1967). Nevertheless, the percentage of both forms of neutrophils, eosinophils and basophils changed in the course of the year (Table 1).

Seasonal prevalences of some diseases may influence the levels of certain blood indices. In spring more inflamatory processes occur which may stimulate the neutrophils (Schalm 1962). In bison the spring increase of leukocyte count and neutrophil percentage was observed only in mature bulls and in young females (Table 1) which is not in agreement of Schalm's data.

The percentage of lymphocytes showed cyclicity only in young females which did not reach sexual maturity. In other groups of bison these cells were present in greater amounts, but no cyclicity was found.

Deptuła and Buczek (1982) state that in calves the most disadvantageous influences are high temperature and high humidity and in these conditions the greatest changes occur in the white blood system in bone marrow and in peripheral blood. No informations exist on the bone marrow in bison.

Wołk (1983) studied the WBC system in 37 European bison, and several of the animals were the same as in this paper, but the study was conducted only in winter time. She divided the animals into four groups: 1 year, $1-4$ years, over 
4 years and over 15 years old. She found that the eosinophil percentage increased with animal age but the lymphocyte percentage decreased with age. She also showed that the mean values were lower in European bison than in American bison and domestic cattle. In this study the leukocyte amount changed in young bison between 4 and nearly $7 \times 10^{9} /$ but in mature ones between 4 and $8 \times 10^{9} /$, while the lymphocyte percentage was nearly the same in all groups.

Some aspects of chronobiology were studied in calves and goat kids. KatungukaRwakishaya et al. (1988) studied the haematological values in 11 calves for 16 weeks of their life. They presented their results only as means values and it is difficult to compare those data with the ones found in this paper. It is very interesting that eosinophil percentage was $0.76 \pm 0.15$ in heifer calves and $4.15 \pm 0.26 \%$ in bulls calves. Białkowski et al. (1988) studied many haematological and biochemical parameters in 16 kids between 2 weeks and 7 months of life, in 6 sampling periods. A decrease in leukocyte number was found as well as in lymphocyte, neutrophil and monocyte percentage, and an increase in eosinophil percentage. The percentage of lymphocytes was high and changed from 75 to $68 \%$ of total WBC number.

To compare with other groups of herbivorous animals let me mention a two-year study on Arabian horses where seasonal cyclicity was found in all groups (two of foals and two of mares) in lymphocyte, segmented neutrophil and eosinophil number (Gill et al. 1985). This corroborates the opinion that different factors may regulate the production and use of the short living cells in different organisms.

The sedimentation rate of blood cells has been mostly studied as a subsidiary factor in diagnostic examination. But it is also given in many physiological handbooks. As early as in 1937 (according to Dukes 1955) Fähraeus stated that the only factor of importance in the sedimentation rate is the degree of agglutination of erythrocytes (and hence the size of the sedimentating particles), and it is certain that the plasma proteins markedly influence this factor. But we still know very little about the bison plasma proteins.

The sedimentation rate in ruminants is very slow. In cattle it is $2.4 \mathrm{~mm}$ in $7 \mathrm{hr}$ and a value over $4 \mathrm{~mm}$ in $7 \mathrm{hr}$ is taken as indicative of a pathological condition (Dukes 1955). In the European bison this rate is much faster: $1-8 \mathrm{~mm} / 15 \mathrm{~min}$ and $3.5-39.0 \mathrm{~mm} / 60 \mathrm{~min}$. As it is seen from Table 1 this rate changed in all groups and in all months. The examined bison did not show changes in haematological indices, in comparison with the mean data found in the same group and in the same month.

From chronobiological point of view this parameter was studied in barren mares of Thoroughbred horses, where it showed distinct treefold cycle with peaks in January, May and the highest one in September (Gill and Wańska 1978). It was recorded after 15, 30, 45, 60 and $120 \mathrm{~min}$. In Arabian mares and foals the sedimentation rate, examined after $15 \mathrm{~min}$, showed cyclicity in all four groups, with the acrophases between mid-June and mid-August (Gill and KompanowskaJezierska 1986). 
Apart from the features of cyclicity and despite the quite fast sedimentation rate the present results indicate that toward the winter time the lymphocyte percentage increases and the sedimentation rate of blood cells decreases. Until now nearly nothing has been known about the immunology of this very interesting animal. But all the results obtained in this and in previous papers indicate that the basal physiological mechanisms in the European bison are different from those known for other big ruminants.

Acknowledgement: This study was partially supported by the scientific programme coordinated by the Warsaw Agricultural University, Poland.

\section{References}

Białkowski Z., Saba L., Bis-Wencel H. and Janecki T. 1988. Zmiany wskaźników hematologicznych, białka ogólnego, glukozy, cholesterolu oraz aktywnosci AP, AspAT i AlAT w surowicy krwi koźląt w pierwszych szesciu miesiącach życia. Med. Wet. 44: 112 - 114. [In Polish with English summary]

Dąbrowski Z. 1987. Fizjologia krwi i chłonki. [In: Zarys fizjologii porównawczej zwierząt. J. Gill, ed.]. PWN - Polish Sci. Publ., Warszawa 1: 135. [In Polish]

Deptuła W. and Buczek J. 1982. Wpływ warunk6w srodowiska na niektore mechanizmy odpornosci bydła. Med. Wet. 38: $51-54$. [In Polish with English summary]

Dukes H. H. 1955. The physiology of domestic animals. Comstock Publ. Ass. Ithaca, New York: $\mathrm{XII}+1-1020$.

Gill J. 1987. Physiological indices of adaptation of European bison to some environmental factors. [In: Abstracts XVIIIth Congr. Intern. Union Game Biol. B. Bobek, K. Perzanowski, W. L. Regelin and R. Tertil, eds]. Jagiellonian University, Krak6w: 67.

Gill J. 1989. Seasonal changes in the red blood cell system in the European bison, Bison bonasus L. Comp. Biochem. Physiol. 92A: 291 - 298.

Gill J. 1990. Seasonal cyclicity in carbohydrate metabolism parameters in the European bison, Bison bonasus L. Comp. Biochem. Physiol. 96A: 435 - 439.

Gill J., Kompanowska-Jezierska E., Jakubów K., Kott A. and Szumska D. 1985. Seasonal changes in the white blood cell system, lyzozyme activity and cortisol level in Arabian brood mares and their foals. Comp. Biochem. Physiol. 81A: 511 - 523.

Gill J. and Kompanowska-Jezierska E. 1986. Seasonal changes in the red blood cell indices in Arabian brood mares and their foals. Comp. Biochem. Physiol. 83A: 643-651.

Gill J. and Wańska E. 1978. Seasonal changes in erythrocyte, hemoglobin and leukocyte indexes in barren mares of Thoroughbred horses. Bull. Acad. Polon. Sci., Ser. Sci. Biol. 26: 347 - 353.

Gutowski B. 1965. Fizjologia zwierząt. PWRiL - Šale Publ. for Agricult. and Forestry, Warszawa: 1 $-553$.

Halberg F., Tong Y. and Joh.son E. A. 1967. Circadian system phase, an aspect of temporal morphology; procedure and illustrative examples. [In: The cellular aspects of biorhythms, symposium on biorhythms.]. Springer Verl., Berlin: $20-48$.

Haus E., Lakantua D. J., Swoyer J. and Sackett-Lundeen L. 1983. Chronobiology in hematology and immunology. Amer. J. Anat. 168: 467 - 517.

Katunguka-Rwakishaya E., Larkin H. and Kelly W. R. 1988. The influence of a growth promoter (Zeranol) on the growth rate, haemogram, myelogram and selected blood biochemical velue of calves. Br. vet. J. 144: $72-80$.

Kokot F. 1969. [Methods of laboratory experiments used in clinics]. PZWL - State Publ. House for Med., Warszawa: XVI + $1-503$. [In Polish] 
Oktaba W. 1977. Elementy statystyki matematycznej i metodyki doswiadczalnictwa. PWN - Polish Sci. Publ., Warszawa: $1-488$.

Pawelski S. 1977. Diagnostyka laboratoryjna w hematologii. PWN - Polish Sci. Publ., Warszawa: $1-412$.

Shalm O. O. 1962. Leukocyte responses to disease in various domestic animals. JAVMA. 140: 557.

Shifrine M. and Rosenblatt L. 1981. Seasonal variations in immunity. J. Immunol. 127: 393.

Wołk E. 1983. The hematology of the free-ranging European bison. Acta theriol. 28: $73-82$.

Received 10 October 1991, revised 8 July 1992, accepted 21 July 1992.

Acta Theriologica 37 (3): 290, 1992.

BOOK REVIEW

\section{Carnivore behavior, ecology, and evolution}

Carnivore behavior, ecology, and evolution. J. L. Gittleman, ed. Chapman and Hall, London, 1989. XIV + 620 pp. ISBN 0-412-34360-6.

The aim of the book was to summarize and evaluate the recent research in carnivore biology. The volume is organized in three parts: behavior, ecology, and evolution. Chapters are written by 30 contributors and each section is preceded by an introduction by J. L. Gittleman, the editor of the volume.

The behavioral part of the book deals with the acoustic and olfactory communication in fissiped carnivores, sociality and behavioral development. It contains extensive reviews of literature and concepts (e.g. chapter on acoustic communication by G. Peters and W. C. Wozencraft) as well as new ideas (e.g. chapter on mating tactics and spacing in solitary carnivores by M. Sandell).

In the ecological part, most of chapters have linked the physiological parameters to the ecological adaptations of carnivores, both the small-sized ones (chapter by C. M. King on constrains of small size in weasels) and the large-sized ones (chapter on ecological constrains on predation by large felids by M. E. and F. C. Sunquist).

The chapters in the part on evolution present the problems which often are the subjects of intense discussion and disagreement. Results of molecular and biochemical techniques of studying evolution (chapter by R. K. Wayne et al.), palaeontological investigations of fossils (L. D. Martin), and comparative osteological studies (W. C. Wozencraft) provide a comprehensive view of our present knowledge on evolution of carnivores. It appears discursive in many points (e.g. the problems of diphyly or monophyly in pinnipeds), but form a necessary background for our understanding the contemporary ecology and status of carnivore species.

The book is equipped with a species and subject index. The volume will be of great value to researchers, students, conservationists, and nonspecialist readers fascinated with carnivores.

Bogumiła JEDRZEJEWSKA and Mieczysław WOLSAN, Mammal Research Institute, Polish Academy of Sciences, 17-230 Białowieża, Poland 